\title{
RECOGNIZING CODE SWITCHING AND CODE MIXING IN TALK SHOW CATATAN NAJWA WITH MAUDY AYUNDA ON YOUTUBE
}

\author{
Sulhiah Wulan Sari, Paramita Kusumawardhani \\ University of Bina Sarana Informatika, Jakarta, Indonesia \\ Sulhizah.szw@bsi.ac.id, Paramita.pmi@bsi.ac.id
}

Submitted : 22/July/2021

Accepted : 11/August/2021

Publication: 13/August/2021

\begin{abstract}
People capable of speaking and writing two languages well are called bilingual. In contrast, the people who use two words or even in a sentence without paraphrase mean code-mixing. The purpose of this study is to know the types of code-switching and code-mixing. Code-switching and code-mixing are parts of sociolinguistics. Sociolinguistics studies an analysis of language. The linguistic factors are related to the factors beyond the language, such as language use done by its speakers in a particular speech community. Code-switching and code-mixing usually happened when talking to someone. The source of the research was the talk show Catatan Najwa with Maudy Ayunda on Najwa Shihab's Channel Youtube. In this talk show, there was a guest star called Maudy Ayunda. She has just recently graduated from Oxford University and had a conversation with Najwa Shihab. The conversation happened on Najwa Shibah's Youtube Channel. In this conversation, they used two languages that are Indonesian and English. This research used the qualitative descriptive method. To complete the data, The researcher also conducted library research. This study focused on video Najwa Shihab's Channel Youtube. The research results are Inter-Sentential with 9 data as the code-switching type and Insertion with 7 data as the code-mixing type.
\end{abstract}

Keywords: Code Switching, Code Mixing, Talk show Catatan Najwa, Youtube

\section{Introduction}

Language is a system of communication that consists of a set of sounds and written symbols used by the people of a particular country or region for talking or writing. Language is a communication used to convey thought, idea, concept, or feeling. Language is essential in people's lives. Language can also be a symbol or sound used to interact with others, so language is the most helpful tool in social life. Linguistics is the scientific study of language and its structure. Linguistics has many specific branches such as syntax, phonetics, phonology, morphology, semantics, historical linguistic, sociolinguistics, psycholinguistics, neurolinguistics, and computational linguistic.

(Collins, 2006) said that sociolinguistics covers a tremendous variety of aspects. (Kurniati, 2014), Sociolinguistic also discusses language characteristics and grammar used in a society wherein there are rules used until now. Sociolinguistics teaches about real-life attitudes and social situations. Sociolinguistics related to bilingualism. (Education \& Program, 2014), said that bilingualism is the phenomenon of speaking and understanding two or more languages. Bilingualism is the ability or habit of a person in using two languages. To use the two languages, one must be an expert in both languages, such as the native language as the first language and other languages as the second.

Code-switching can be defined as using more than one language, variety, or style by a speaker within an utterance or discourse or between different interlocutors or situations. Code-switching is often used when communicating in society rather than writing. Code mixing is a change of one language to another language in the exact oral or written text. Code 
mixing is the use of a speech from one language to another to extend the style of language in use when speaking.

Based on the expert's explanation above, it can be concluded that some aspects influence the language, one of them is sociolinguistics. In sociolinguistics, code-switching and codemixing usually happen. They happen because there are many people in society, and they have their dialect. Code-switching and code-mixing also happen to bridge the language gap.

\section{Literature Review \\ Definition of Sociolinguistics}

Language provides a variety of ways of saying something in some social context. Sociolinguistics is concerned with the relationship between language and the context in which it is used. According to (Putra \& Yastanti, 2018), "Sociolinguistics is inter-discipliner between sociology and linguistics which have a close relation.' It means that sociolinguistic connect between sociology and linguistic. Sociolinguistic creates the language itself and also its usage in society due to their relation to each other. Sociolinguistics was derived from the word sociology and linguistics. Sociology is the study of the structure and social processes that occur in society. Meanwhile, the understanding of linguistics is the study of the system of language usage.

Sociolinguistics studies and talked about the states of language society, especially the types related to social factors. Therefore, sociolinguistics is a part of linguistics that studies the aspect of language in society, particularly the differences in language about social factors in society itself. Sociolinguistics gives guidelines to us in communication by showing language and variety of language used in communicating by a certain person.

According to Chaer and Agustina as cited in (Isti, 2013) stated "Sociolinguistics is inter-discipliner between sociology and linguistics which have a close relation.' It means that sociolinguistic connect between sociology and linguistic. Sociolinguistic creates the language itself and also its usage in society due to their relation to each other. Sociolinguistics was derived from the word sociology and linguistics. Sociology is the study of the structure and social processes that occur in society. Meanwhile, the understanding of linguistics is the study of the system of language usage.

(Khairunas \& Inggris, 2016), "Sociolinguistics is concerned with investigating the relationship between language and society with the goal being better under a standing of the structure of language and how languages function in communication." Based on the statement, in sociolinguistics, we study both language and society to learn more about the language and its function.

Based on the explanation above, The writer can summarize that sociolinguistic is the result of research within the scope of society related to the use of language structures and functions as a means of communication. Sociolinguistics is also associated with bilingualism.

\section{Definition of Bilingualism}

Bilingualism is the ability to use two languages. Bilingualism is a topic that has been studied from many perspectives. Broadly defined, bilingualism refers to knowledge and command of two or more languages, albeit to different degrees. (Maftoon, 2016) said that Bilingualism is a significant fact of life in the world today. People, who are brought up in a society where monolingualism and uniculturalism are promoted as the norm, often think of bilingualism as a rare phenomenon.

According to Harimurti (Kurniati, 2014), "Bilingualism is interrelated with the individual and society by two languages, how both of language used and how they studied." The writer believes that bilingualism is relevant to society by using a foreign language and how they can apply it intentionally. 
Taken from (Nuryanto, 2014), "Bilingualism is the ability of an individual or the members of a community to use two languages effectively." The writer concluded the skill of a person or group in society using two languages.

Fromkin, Rodman, \& Hymas in (Yastanti, 2016), "Bilingualism (or multilingualism) also refers to the situation in nations in which two (or more) languages are spoken and recognized as official or national languages." It can be shown that bilingualism or multilingualism are two more languages used in a country as the official and national languages.

Based on the explanation above, it can be concluded that bilingualism related to two languages happens simultaneously in communication. Bilingualism encompasses a range of proficiencies and contexts. Bilingualism can occur when there are many backgrounds of people in one society.

\section{Definition of Code Switching and Code Mixing}

(Adriana dan Ratmo, 2017), "Code is a speaker system whose language elements applied has characteristics appropriate to the background, speaker, and speaker's relation with the addressee in the speech situation." By that statement, code is language variation and has specific or unique characteristics related to the speaker's utterances, writings, or speeches affected by the background and situation.

(Pendidikan Bahasa, Fkip, \& Banjarmasin, 2019) also, say that "code-mixing is a language influenced in conversation and there are some insertions of other languages." It means code-switching is similar to code-mixing which the first process is the speaker switches from one code to another code (also can be said one language into another language).

(Putra \& Yastanti, 2018), "Code-switching (CS) is one of the popular research topics in linguistics because it is a widespread phenomenon in most bilingual societies." It is, on the other hand, used and applied by many people to communicate and have an interaction with each other" Basically, code-switching happens when the speaker decides to have more than one language on their utterances or speeches and switch it from one code into another code that leads to mixing two or more languages or usually called as code-switching.

Furthermore, based on (Siregar, Bahri, \& Sanjaya, 2014) ), code-switching is the use of two or even more changing languages; it can be on some variations in terminology. From the statement, codeswitching two languages or more happens in a sentence on some variations.

(Yastanti, 2016), "Code mixing occurs when a conversation uses both languages together to the extent that they change from one language to another in the course of a single utterance" means Code mixing occurs when there is a conversation that uses two languages so will change the meaning of the language.

In conclusion that basically, code-switching happens when the speaker decides to have more than one language on their utterances or speeches and switch it from one code into another code that leads to mixing two or more languages or usually called code-switching. Code-mixing is a mixing of two codes or languages, usually without a change of topic. Code mixing often occurs within one sentence. In code-mixing sentences, pieces of one language are used while a speaker uses another language.

\section{Types of Code Switching}

Code-switching occurs in different situations. The classifications types of codeswitching can be based on the reason why people switch their language. (Khairunas, 2018) distinguishes "two main types of code-switching: Situational and Metaphorical."

Situational refers to a language change depending on contextual factors which have nothing to do with the topic but with the given situation. Meanwhile, Metaphorical points to the case and the contents of the communicative process as the main reason for language choice. The alternate code often encodes personal and social values that add interpersonal closeness or distance. 
Besides the factor reasons, types of code-switching also can be categorized based on grammatical classification. Poplack in (Khairunas, 2018) classified code-switching into three types :

Extra-sentential code-switchingExtra-sentential code-switching involves the insertion of a tag or exclamation, like "you know," "I mean," in one language into a sentence that is otherwise in the other language. Example: It's okay, no problem, ya nggak?

\section{Inter-sentential code-switching}

Inter-sentential code-switching describes a switch of language varieties at the sentence boundary or between the sentences. As a result, a sentence or a part of a sentence can occur in one language and the following position in a different one. Example: I'm good, kamu lagi ngapain?

\section{Intra-sentential code-switching}

Intra-sentential code-switching is used to refer to a switch within a sentence. More precisely, in intra-sentential code-switching, the switch to a different language can occur within the clause boundary or even within the word boundary. Further supported by Jendra in (Astri \& Octavita, 2016), "An intra-sentential switching is found when a word, a phrase, or a clause of a foreign language is found within the sentence in a base language." Example: What's up bro? Gila loe tuh lagi trending topic dimana-mana.In conclusion, there are various types of code-switching served by experts. Some experts categorized it into several factors reason and factor grammatical classification.

\section{Types of Code Mixing} followed by:

According to Hoffman (Astri \& Octavita, 2016) based on syntactical patterns as

\section{Intra-Sentential Code Mixing}

This kind of code-mixing occurs within a phrase, a clause, or a sentence boundary, for example, English-Indonesian.

\section{Intra-Lexical Code Mixing}

This kind of code-mixing occurs within a word boundary, for example, from English to Indonesia:

\section{Involving a Change of Pronunciation}

This kind of code-mixing occurs at the phonological level, as when Indonesian people say an English word but modify it into Indonesian phonological structure.

It concluded that code-mixing has three types: insertion, alternation, and congruent lexicalization, which is very influential when word mixing uses two languages at more.

\section{Definition of Talk Show}

(Khairunas, 2018), "Talkshow is governed by a set of rules or guiding principles that make it distinct from any other form of TV soap opera, news, or game shows, for instance-and also from daily conversation. It is unscripted yet highly planned and invariably anchored by an announcer, host, or team of hosts." It means that a talk show is a program of television that different from any other form of television; it is unscripted but planned well and anchored by an announcer or host.

A talk show as a genre of institutional talk is primarily designed for overhearing the audience, the studio audience, and the TV viewers. In line with (Khairunas, 2018), "The talk show is a genre predicated on active audience response, not silent and anonymous voyeurism." It means talk show influences the audience to interact actively.

Unlike other television programs, talk shows provide light entertainment and interesting topics but are still humorous and give helpful information to the viewers. (Khairunas, 2018) states that talk show has traditionally been devoted to either light 
entertainment, with comedy, skits, music, and celebrity guests, or more severe discussion of news and public affairs among experts. A defined talk show is a program that is entertaining and contains much information for the viewers.

From all the definitions above, it can be concluded that a talk show is a format of a television show that contains discussion or talks between the host and the guest stars to give entertainment and useful information to the audience or viewer with a relaxed atmosphere, the topic to be discussed can be about career, music, sport, lifestyle, etc.

\section{Definition of Youtube}

Youtube is one of the most popular social media for sharing audio-visual on the internet, which is everyone can upload and watch any videos. According to (Alias, Razak, elHadad, Kunjambu, \& Muniandy, 2013), "Youtube began in February 2005 and was founded by Chad Hurley, Steve Chen, and Jawed Karim who named it "Youtube.com." through the Youtube platform, people started to create a video-sharing website on which users could upload, share, and view videos. One more thing that is most dominant from youtube is there are so many new generations of amateur video makers." So here, it can be concluded that Youtube is one of the social media that the users can view and exchange.

According to (Thanissaro \& Kulupana, 2015)

"Youtube is one of the services of Google, facilitating its users to upload videos and can be accessed by different users of the world for free. You could say Youtube is the most popular video database in the internet world, or maybe even the most complete and varied. Google did not originally develop Youtube, but Google acquired it and then read other Google services. Youtube has now become a variety of needs from its users; features complemented by the advancement of Youtube technology are now benefiting from the user's various needs. It has more than one billion users, all one-third of all internet users, and every day people watch hundreds of hours of videos on Youtube and generate millions of views. Youtube, as a whole, has found more viewers who have 8-34 and 18-49 years, any cable network in the world. Youtube is also an excellent resource for online videos. This site is very different in its offerings for users. Long videos, audiences, and available tools vary. "Streaming Video Resources for Teaching, Learning, and Research" will also include excellent open access, all sections, and online video initiatives, and interdisciplinary sites with online video collections in various categories and topics."

From the statement above, Youtube is one Google branch video-sharing online service that facilitating people to share another video for any needs or purposes.

\section{Research Method}

A qualitative descriptive approach to data collection and analysis is used in this research. The data analysis is obtained from the Talk Show 'Catatan Najwa with Maudy Ayunda on Youtube.' This Talk Show was released on 22 March 2019 on YouTube Channel. It consists of 4 data analyses taking from the content in the recording of the speaker's utterance. The research method used in this research is content analysis. Content analysis is one of the types of textual analysis that differs from the other two types: discourse analysis and conversation analysis (Truex in Astri \& Octavita, 2016). When discussing the recording unit in content analysis, it states that the recording unit is the specific segment of content characterized by placing it in a given category. Content analysis is also indicated as a structural tool that can search for patterns at a word or phrase level. According to Neuman (Astri \& Octavita, 2016), content analysis is a method of obtaining and interpreting textual information. Words, meanings, visuals, symbols, ideas, themes, or any message that may be expressed are all examples of content. Text is defined as anything written, visible, or spoken that acts as a medium of communication. 
IJEAL (International Journal of English Education and Applied Linguistic)

Volume : 1 | Number 2 | August 2021 | E-ISSN : 2787-9482 | DOI: doi.org/ijeal.v1n1.1029

Based on that explanation, the procedure of the analysis in this research is beginning with finding on the appropriated object analysis in the talk show of Catatan Najwa with Maudy Ayunda on YouTube, looking at the speaker's utterance in the recording of the Talk Show, tabulated the data analysis into several items of topic discussion, analyzing the content in the sentences and finding the appropriated code-switching and code-mixing, completing the data with library research, discovering the reason or the cause of the code-switching in the sentences, and finding the types of code-switching and code-mixing in the collected data.

\section{Results and Discussion}

The contents in the YouTube channel of Catatan Najwa with Maudy Ayunda can be tabulated into several items as the types of code-switching in table 1:

\begin{tabular}{|c|c|c|c|c|}
\hline No & Utterance & Speaker & $\begin{array}{l}\text { Code- } \\
\text { Switching }\end{array}$ & Reason \\
\hline 1. & $\begin{array}{l}\text { Sekarang saya bersama the one and } \\
\text { only yang tersayang, Maudy Ayunda. } \\
(00: 00: 15)\end{array}$ & $\begin{array}{l}\text { Najwa } \\
\text { Shihab }\end{array}$ & $\begin{array}{c}\text { Intra- } \\
\text { Sentential }\end{array}$ & $\begin{array}{lr}\text { a phrase within } \\
\text { sentence of Code } \\
\text { Switching. }\end{array}$ \\
\hline 2. & $\begin{array}{l}\text { So happy to be here, Mbak. } \\
(00: 00: 21)\end{array}$ & $\begin{array}{l}\text { Maudy } \\
\text { Ayunda }\end{array}$ & $\begin{array}{c}\text { Inter- } \\
\text { Sentential }\end{array}$ & $\begin{array}{l}\text { The Code Switching } \\
\text { happens at the } \\
\text { beginning of a sentence. }\end{array}$ \\
\hline 3. & $\begin{array}{l}\text { Terus kalau setiap aku baca dan nge- } \\
\text { browsing, pokonya ceritanya serem } \\
\text { lah, you will never get in lah! Harus } \\
\text { nilainya segini lah, gini-gini, pokonya } \\
\text { aku takut banget gitu. ( } 00: 01: 25 \text { ) }\end{array}$ & $\begin{array}{l}\text { Maudy } \\
\text { Ayunda }\end{array}$ & $\begin{array}{c}\text { Extra- } \\
\text { Sentential }\end{array}$ & $\begin{array}{l}\text { In here, Maudy gives an } \\
\text { exclamation with her } \\
\text { words "you will never } \\
\text { get in lah!" The words } \\
\text { prove the truth. }\end{array}$ \\
\hline 4. & $\begin{array}{l}\text { What so special about it ? Apa } \\
\text { karena masuknya susah jadi tertantang } \\
\text { atau ada something yang lain ? } \\
00: 01: 44)\end{array}$ & $\begin{array}{l}\text { Najwa } \\
\text { Shihab }\end{array}$ & $\begin{array}{c}\text { Intra- } \\
\text { Sentential }\end{array}$ & $\begin{array}{l}\text { Based on the sentence, } \\
\text { only a phrase is in the } \\
\text { switch of language. }\end{array}$ \\
\hline 5. & $\begin{array}{l}\text { Dan dari cerita-cerita mereka, they } \\
\text { feel like they've grown, dari that } \\
\text { experience, aku emang interested in } \\
\text { business juga and like techonology, } \\
\text { dan the idea of studying deket banget } \\
\text { dari Silicon Valley. (00:01:55) }\end{array}$ & $\begin{array}{l}\text { Maudy } \\
\text { Ayunda }\end{array}$ & $\begin{array}{l}\text { Extra- } \\
\text { Sentential }\end{array}$ & $\begin{array}{l}\text { In this sentence, Maudy } \\
\text { tells her friend's story, } \\
\text { so the writer thinks the } \\
\text { sentence includes the } \\
\text { type Extra-Sentential of } \\
\text { Code-Switching. }\end{array}$ \\
\hline 6. & $\begin{array}{l}\text { And approach-nya Standford tuh juga } \\
\text { sangat experience-based. Dan dia } \\
\text { juga have a very good education } \\
\text { school. ( } 00: 02: 25)\end{array}$ & $\begin{array}{l}\text { Maudy } \\
\text { Ayunda }\end{array}$ & $\begin{array}{c}\text { Inter- } \\
\text { Sentential }\end{array}$ & $\begin{array}{l}\text { Code-Switching occurs } \\
\text { in sentence boundary. }\end{array}$ \\
\hline 7. & $\begin{array}{l}\text { Jadi walaupun major-nya itu tapi you } \\
\text { can choose and pick and choose } \\
\text { from others schools? }\end{array}$ & $\begin{array}{l}\text { Najwa } \\
\text { Shihab }\end{array}$ & $\begin{array}{c}\text { Inter- } \\
\text { Sentential }\end{array}$ & $\begin{array}{l}\text { Code-Switching occurs } \\
\text { in sentence boundary. }\end{array}$ \\
\hline
\end{tabular}




\begin{tabular}{|c|c|c|c|c|}
\hline & $(00: 02: 31)$ & & & \\
\hline 8. & $\begin{array}{l}\text { It's something wow! Like all the } \\
\text { smart people go there, and imagine } \\
\text { how much I can learn, kaya gitu-gitu } \\
\text { masih yang segitu aja. (00:03:51) }\end{array}$ & $\begin{array}{l}\text { Maudy } \\
\text { Ayunda }\end{array}$ & $\begin{array}{c}\text { Extra- } \\
\text { Sentential }\end{array}$ & $\begin{array}{l}\text { Based on Maudy's } \\
\text { words contain an } \\
\text { exclamation like "It's } \\
\text { something wow!" }\end{array}$ \\
\hline 9. & $\begin{array}{l}\text { Ternyata kalau kita memberikan } \\
\text { energi positif terhadap impian kita, } \\
\text { take we think about it, which I } \\
\text { did all the time. It's more like I } \\
\text { didn't get it can happen. } \\
(00: 07: 26)\end{array}$ & $\begin{array}{l}\text { Maudy } \\
\text { Ayunda }\end{array}$ & $\begin{array}{c}\text { Inter- } \\
\text { Sentential }\end{array}$ & $\begin{array}{l}\text { Code-Switching occurs } \\
\text { in one language and in } \\
\text { different parts with } \\
\text { different languages. }\end{array}$ \\
\hline 10. & $\begin{array}{l}\text { Aku juga percaya banget itu, aku } \\
\text { selalu percaya omongan bagus, } \\
\text { positif, kalo kita we will believe it, we } \\
\text { can do it sih! ( } 00: 07: 42 \text { ) }\end{array}$ & $\begin{array}{l}\text { Najwa } \\
\text { Shihab }\end{array}$ & $\begin{array}{c}\text { Extra- } \\
\text { Sentential }\end{array}$ & $\begin{array}{l}\text { This sentence contains } \\
\text { an exclamation. }\end{array}$ \\
\hline 11. & $\begin{array}{l}\text { Kalau yang Harvard itu mereka ga } \\
\text { terlalu ada arahan, pokonya lebih yang } \\
\text { kaya "Why wanna do the program? } \\
\text { Why wanna do this" bla, bla, bla. ( } \\
\text { 00:08:30) }\end{array}$ & $\begin{array}{l}\text { Maudy } \\
\text { Ayunda }\end{array}$ & $\begin{array}{c}\text { Inter - } \\
\text { Sentential }\end{array}$ & $\begin{array}{l}\text { The switch of language } \\
\text { occurs at the sentence } \\
\text { boundary. }\end{array}$ \\
\hline 12. & $\begin{array}{l}\text { Kalau yang Standford itu } \\
\text { pertanyaannya What's matter do you } \\
\text { and why } ?(00: 08: 39)\end{array}$ & $\begin{array}{l}\text { Maudy } \\
\text { Ayunda }\end{array}$ & $\begin{array}{c}\text { Inter- } \\
\text { Sentential }\end{array}$ & $\begin{array}{l}\text { The switch of language } \\
\text { occurs at the sentence } \\
\text { boundary. }\end{array}$ \\
\hline 13. & $\begin{array}{l}\text { Boleh aku tau jawabannya apa, Oh is } \\
\text { that to personal ? } \\
(00: 08: 49)\end{array}$ & $\begin{array}{l}\text { Najwa } \\
\text { Shihab }\end{array}$ & $\begin{array}{c}\text { Intra- } \\
\text { Sentential }\end{array}$ & $\begin{array}{l}\text { Based on the sentence, } \\
\text { only a phrase is in the } \\
\text { switch of language. }\end{array}$ \\
\hline 14. & $\begin{array}{l}\text { No, I can know you. Jadi kalo yang } \\
\text { What's matters do you, itu aku } \\
\text { bilang authenticity jadi kaya kejujuran } \\
\text { dalam berkarya. (00:08:51) }\end{array}$ & $\begin{array}{l}\text { Maudy } \\
\text { Ayunda }\end{array}$ & $\begin{array}{c}\text { Extra- } \\
\text { Sentential }\end{array}$ & $\begin{array}{l}\text { Code-Switching } \\
\text { involves the insertion of } \\
\text { a tag an exclamation. }\end{array}$ \\
\hline 15. & $\begin{array}{l}\text { And I'd like my friend told me, } \\
\text { Don't that the one gitu. If that's the } \\
\text { one it's closest to you. }(00: 10: 41)\end{array}$ & $\begin{array}{l}\text { Maudy } \\
\text { Ayunda }\end{array}$ & $\begin{array}{c}\text { Inter- } \\
\text { Sentential }\end{array}$ & $\begin{array}{l}\text { The Code Switching } \\
\text { occurs in the first } \\
\text { sentence and sentence } \\
\text { boundary. }\end{array}$ \\
\hline 16. & $\begin{array}{l}\text { Tapi in a way, aku juga gabisa, I } \\
\text { dont wanna deny the fact than you } \\
\text { know my background as a lot, rule- } \\
\text { nya juga cukup besar lah in bringing } \\
\text { me here. (00:14:16) }\end{array}$ & $\begin{array}{l}\text { Maudy } \\
\text { Ayunda }\end{array}$ & $\begin{array}{c}\text { Extra- } \\
\text { Sentential }\end{array}$ & $\begin{array}{l}\text { In this sentence, Maudy } \\
\text { is clarifying to the } \\
\text { others for giving a } \\
\text { prove about her career, } \\
\text { in here the writer thinks } \\
\text { the suitable type is } \\
\text { Extra-Sentential. }\end{array}$ \\
\hline
\end{tabular}




\begin{tabular}{|c|c|c|c|c|}
\hline 17. & $\begin{array}{l}\text { All of these people yang justru kaya } \\
\text { role tuh sebagai musisi/artis. Actually } \\
\text { it's be a challenge. You know I am } \\
\text { capable of doing the word and I } \\
\text { really fashionate about that karena } \\
\text { sebenarnya bidang aku beda. ( } \\
00: 14: 47)\end{array}$ & $\begin{array}{l}\text { Maudy } \\
\text { Ayunda }\end{array}$ & $\begin{array}{c}\text { Extra- } \\
\text { Sentential }\end{array}$ & $\begin{array}{l}\text { From Maudy's words, } \\
\text { she tries to clarify again } \\
\text { about her career. } \\
\text { Therefore, the writer } \\
\text { chooses a type of Extra- } \\
\text { Sentential. }\end{array}$ \\
\hline 18 & $\begin{array}{l}\text { I don't agreekarena sebenarnya dalam } \\
\text { teman-teman musisi berkarya in the } \\
\text { way, they do, they work, they } \\
\text { produce music and produce lyric } \\
\text { atau dalam dunia perfilman orang- } \\
\text { orang membuat karya itu sangat - } \\
\text { intelektual }(00: 15: 50)\end{array}$ & $\begin{array}{l}\text { Maudy } \\
\text { Ayunda }\end{array}$ & $\begin{array}{c}\text { Intra- } \\
\text { Sentential }\end{array}$ & $\begin{array}{l}\text { There are some clauses } \\
\text { in the sentence. }\end{array}$ \\
\hline 19. & $\begin{array}{l}\text { Aku merasa bahwa apapun yang kita } \\
\text { pelajarin there's no limit to anyone if } \\
\text { they wanna learn it. Jadi ada } \\
\text { something yang very powerful about } \\
\text { learning. } \\
(00: 16: 53)\end{array}$ & $\begin{array}{l}\text { Maudy } \\
\text { Ayunda }\end{array}$ & $\begin{array}{c}\text { Inter- } \\
\text { Sentential }\end{array}$ & $\begin{array}{l}\text { The writer finds the } \\
\text { switch of language } \\
\text { occurs in one language, } \\
\text { and it is at the sentence } \\
\text { boundary. }\end{array}$ \\
\hline 20. & $\begin{array}{l}\text { Aku honestly, felt like I was beating } \\
\text { this all this. Wah aku langsung } \\
\text { merasa kaya you know this is a } \\
\text { privilage, this is a something that } \\
\text { I'm lucky to have opportunity, dan I } \\
\text { have to do something. Aku kembali } \\
\text { ke Indonesia, contribute in Indonesia } \\
\text { kaya ada a little bit of that. }(00: 20: 45)\end{array}$ & $\begin{array}{l}\text { Maudy } \\
\text { Ayunda }\end{array}$ & $\begin{array}{c}\text { Extra- } \\
\text { Sentential }\end{array}$ & $\begin{array}{l}\text { Based on the sentence, } \\
\text { Maudy explains her } \\
\text { feeling. The writer } \\
\text { thinks, when Maudy } \\
\text { explains her feeling, she } \\
\text { uses an exclamation } \\
\text { word. So, the suitable } \\
\text { type is Extra-Sentential }\end{array}$ \\
\hline
\end{tabular}

\section{Tabel 1. Types of Code Switching}

Twenty data in table 1 shows that the most types of code-switching found in the utterance of both speakers are extra-sentential with 8 data. Those utterances rely on the use of a tag or exclamation as they are implied in the number of the sentence of data 3 (You will never get in lah!), 8 (It is something wow!), 10 (we will believe it, we can do it sih!), 14 (No, I can know you...), 17 (Actually it is a challenge. You know I am capable of doing the word and I passionate about that Karena sebenarnya bidang Aku beda), and 20 (you know this is a privilege, this is a something that I'm lucky to have an opportunity, dan I have to do something). The case in data 5,14, 16 show that the sentences do not show the tag, but it can be clear to the meaning of the text that consists of exclamation statements.

Meanwhile, in the table, data 2, 6, 7, 9, 11, 12, 15, 19) can be categorized as intersentential because they are part of a phrase that can appear in just one language. Still, the subsequent expression can be found in another language, as in the sentences "So happy to be here, Mbak." The phrase 'Mbak' appears in the English language.

Intra-sentential code-switching is found in this analysis about 4 data $(1,4,13,18)$. The utterances as in the sentences "Apa karena masuknya susah jadi tertantang atau ada something yang lain" and other data $(1,13,18)$ in table 1 are involved as intra-sentential code because it is possible to see that there is transition within a sentence when a word, phrase, or clause from a foreign language comes within a sentence written in the base 
IJEAL (International Journal of English Education and Applied Linguistic)

Volume : 1 | Number 2 | August 2021 | E-ISSN : 2787-9482 | DOI: doi.org/ijeal.v1n1.1029

language. In this example, the term 'something' as the foreign language is inserted into the base language (Indonesian language).

\begin{tabular}{|c|c|c|c|c|}
\hline No & Utterance & Speaker & $\begin{array}{c}\text { Code } \\
\text { Mixing }\end{array}$ & Reason \\
\hline 1. & $\begin{array}{l}\text { Tapi kan sebenarnya yang } \\
\text { Harvard apply-nya pendidikan } \\
\text { leducation, kalau Standford } \\
\text { business administration memang } \\
\text { pilihannya waktu itu memilih } \\
\text { major yang berbeda di } 2 \text { kampus } \\
\text { yang berbeda pertimbangannya } \\
\text { seperti apa? }\end{array}$ & $\begin{array}{l}\text { Najwa } \\
\text { Shihab }\end{array}$ & Insertion & $\begin{array}{l}\text { Because in the } \\
\text { sentence, Najwa } \\
\text { Shihab inserted } \\
\text { some words of } \\
\text { English when she } \\
\text { was speaking. }\end{array}$ \\
\hline 2. & $\begin{array}{l}\text { Terus kalau setiap aku baca dan } \\
\text { nge-browsing, pokonya ceritanya } \\
\text { serem lah, you will never get } \\
\text { inlah, harus nilainya segini lah, } \\
\text { gini-gini, pokonya aku takut } \\
\text { banget gitu. }\end{array}$ & $\begin{array}{l}\text { Maudy } \\
\text { Ayunda }\end{array}$ & Insertion & $\begin{array}{l}\text { Based on the } \\
\text { sentence, Maudy } \\
\text { Ayunda inserted an } \\
\text { English word. }\end{array}$ \\
\hline 3. & $\begin{array}{l}\text { What so special about it ? Apa } \\
\text { karena masuknya susah jadi } \\
\text { tertantang atau ada something } \\
\text { yang lain? }\end{array}$ & $\begin{array}{l}\text { Najwa } \\
\text { Shihab }\end{array}$ & Alternation & $\begin{array}{l}\text { In the sentence, } \\
\text { there is an equality } \\
\text { between Code } \\
\text { Switching and Code } \\
\text { Mixing. }\end{array}$ \\
\hline 4. & $\begin{array}{l}\text { Dan dari cerita-cerita mereka, } \\
\text { they feel like they've really } \\
\text { grown, dari that experience, aku } \\
\text { emang interested in business juga } \\
\text { and like techonology, dan the idea } \\
\text { of studying deket banget dari } \\
\text { Silicon Valley. }\end{array}$ & $\begin{array}{l}\text { Maudy } \\
\text { Ayunda }\end{array}$ & Insertion & $\begin{array}{l}\text { There are some } \\
\text { Code Mixing are } \\
\text { inserted in Maudy's } \\
\text { words. }\end{array}$ \\
\hline 5. & $\begin{array}{l}\text { And approach-nya Standford tuh } \\
\text { juga sangat experience-based. Dan } \\
\text { dia juga have a very good } \\
\text { education school. }\end{array}$ & $\begin{array}{l}\text { Maudy } \\
\text { Ayunda }\end{array}$ & Insertion & $\begin{array}{l}\text { There are } 2 \text { words } \\
\text { phrases are inserted } \\
\text { in this sentence. }\end{array}$ \\
\hline 6. & $\begin{array}{l}\text { Jadi walaupun major-nya itu tapi } \\
\text { you can choose and pick and } \\
\text { choose from others schools? }\end{array}$ & $\begin{array}{l}\text { Najwa } \\
\text { Shihab }\end{array}$ & Insertion & $\begin{array}{l}\text { The word "major" is } \\
\text { inserted } \quad \text { when } \\
\text { Najwa } \\
\text { speaking. }\end{array}$ \\
\hline 7. & $\begin{array}{l}\text { No, I can know you. Jadi kalo } \\
\text { yang What's matters do you, itu } \\
\text { aku bilang authenticity jadi kaya } \\
\text { kejujuran dalam berkarya. }\end{array}$ & $\begin{array}{l}\text { Maudy } \\
\text { Ayunda }\end{array}$ & Alternation & $\begin{array}{l}\text { Based on the } \\
\text { sentence, There is } \\
\text { equality } \\
\text { Maudy when } \\
\text { "authenticity". }\end{array}$ \\
\hline
\end{tabular}


IJEAL (International Journal of English Education and Applied Linguistic)

Volume : 1 | Number 2 | August 2021 | E-ISSN : 2787-9482 | DOI: doi.org/ijeal.v1n1.1029

\begin{tabular}{|c|c|c|c|c|}
\hline 8. & $\begin{array}{l}\text { Tapi in a way, aku juga gabisa, I } \\
\text { dont wanna deny the fact than } \\
\text { you know my background as a } \\
\text { lot,rule-nya juga cukup besar lah - } \\
\text { in bringing me here. }\end{array}$ & $\begin{array}{l}\text { Maudy } \\
\text { Ayunda }\end{array}$ & Alternation & $\begin{array}{l}\text { The code mixing } \\
\text { occurs in the } \\
\text { beginning and at the } \\
\text { end of a sentence. }\end{array}$ \\
\hline 9. & $\begin{array}{l}\text { All of these people yang justru } \\
\text { kaya role tuh sebagai musisi/artis. } \\
\text { Actually it's be a challenge. You } \\
\text { know I am capable of doing the } \\
\text { word and I really fashionate } \\
\text { about that karena sebenarnya } \\
\text { bidang aku beda. }\end{array}$ & $\begin{array}{l}\text { Maudy } \\
\text { Ayunda }\end{array}$ & Insertion & $\begin{array}{l}\text { There are the words } \\
\text { phrase like "All of } \\
\text { these people" that is } \\
\text { inserted at the } \\
\text { beginning of } \\
\text { sentence and "role" } \\
\text { in the middle of a } \\
\text { sentence. }\end{array}$ \\
\hline 10. & $\begin{array}{l}\text { I don't agreekarena sebenarnya } \\
\text { dalam teman-teman musisi } \\
\text { berkarya in the way, they do, } \\
\text { they work, they produce music } \\
\text { and produce lyric atau dalam } \\
\text { dunia perfilman orang-orang } \\
\text { membuat karya itu sangat - } \\
\text { intelektual. }\end{array}$ & $\begin{array}{l}\text { Maudy } \\
\text { Ayunda }\end{array}$ & Alternation & $\begin{array}{l}\text { The Code Mixing } \\
\text { occurs at the } \\
\text { beginning of the } \\
\text { sentence and the end } \\
\text { of the sentence. }\end{array}$ \\
\hline 11. & $\begin{array}{l}\text { Aku merasa bahwa apapun yang } \\
\text { kita pelajarin there's no limit to } \\
\text { anyone if they wanna learn it. } \\
\text { Jadi ada something yang very } \\
\text { powerful about learning. }\end{array}$ & $\begin{array}{l}\text { Maudy } \\
\text { Ayunda }\end{array}$ & Insertion & $\begin{array}{l}\text { There are some } \\
\text { words phrases are } \\
\text { inserted in the } \\
\text { sentence. }\end{array}$ \\
\hline 12. & $\begin{array}{l}\text { Aku honestly, felt like I was } \\
\text { beating this all this. Wah aku } \\
\text { langsung merasa kaya you know } \\
\text { this is a privilage, this is a } \\
\text { something that I'm lucky to } \\
\text { have opportunity, dan I have to } \\
\text { do something.Aku kembali ke } \\
\text { Indonesia, contribute in Indonesia } \\
\text { kaya ada a little bit of that. }\end{array}$ & $\begin{array}{l}\text { Maudy } \\
\text { Ayunda }\end{array}$ & Alternation & $\begin{array}{l}\text { There are some } \\
\text { code-mixing that } \\
\text { occurs in the } \\
\text { beginning and at the } \\
\text { end of the sentence, } \\
\text { and there is an } \\
\text { equality word in the } \\
\text { sentence. }\end{array}$ \\
\hline
\end{tabular}

Table 2. Types of Code Mixing

The finding on the types of code-mixing in table 2 is 12 data. They are two types of code-mixing; insertion and alteration. Insertion shows 7 data in data 1, 2, 4, 5, 6, 9, and 11. Some words of English phrase are inserted in the sentence of Indonesian language as in the sentence "Terus kalau setiap aku baca dan nge-browsing, pokonya ceritanya serem lah, you will never get in lah". The sentence "you will never get in" is inserted into the Indonesian language.

Meanwhile, alternation consists of 5 data $(3,7,8,10)$. Those sentences in 5 data have used the translation from English into Indonesian, as in the example "Aku honestly, felt like I was beating this all this. Wah Aku langsung merasa kaya you know this is a privilege...". The English sentence "felt like I was beating this all this" has the same meaning as the Indonesian version "Wah Aku langsung merasa kaya". Both of the sentences reveal the feeling of the speaker using the keyword "felt in English and merasa in the Indonesian language. 
At this point, there is no data in the classification of Congruent Lexicalization or the change of pronunciation (Dialect) used in the speaker's utterances.

\section{Conclusion}

Based on the video on Najwa Shihab's channel youtube, code-switching and codemixing were used in the talk show Najwa Shihab with Maudy Ayunda. The kinds of codeswitching are Extra-sentential, Inter-sentential, Intra-sentential. Extra-sentential with 9 data, Inter-sentential with 9 data, and Intra-sentential with 3 data. The most types of code-switching in talk show Catan Najwa with Maudy Ayunda are Extra-sentential and Inter-sentential with 9 data. The kinds of code-mixing are Insertion, Alternation, and Congruent Lexicalization (Dialect). They are with Insertion 7 data, alternation with 5 data, Congruent Lexicalization (Dialect) is no data. The most type of code-mixing found in the talk show Catatan Najwa with Maudy Ayunda is Insertion with 7 data. The additional study can be undertaken in this Talk Show by evaluating the speaker's statement's grammatical errors and semantic analysis.

\section{References}

-, S., Siregar, M., Bahri, S., \& Sanjaya, D. (2014). Code Switching and Code Mixing in Indonesia: Study in Sociolinguistics? English Language and Literature Studies, 4(1), 77-92. https://doi.org/10.5539/ells.v4n1p77

Adriana dan Ratmo. (2017). Code Mixing and Code Switching in "Hitam Putih " Television Program. Paradigma Lingua, 2(1), 3-15. Retrieved from http://openjournal.unpam.ac.id/index.php/Paradigma/article/view/406

Alias, N., Razak, S. H. A., elHadad, G., Kunjambu, N. R. M. N. K., \& Muniandy, P. (2013). A Content Analysis in the Studies of YouTube in Selected Journals. Procedia - Social and Behavioral Sciences, 103, 10-18. https://doi.org/10.1016/j.sbspro.2013.10.301

Astri, R., \& Octavita, I. (2016). CODE MIXING AND CODE SWITCHING IN NOVEL THE DEVIL WEARS PRADA BY LAUREN WEISBERGER : A SOCIOLINGUISTIC STUDY, 01(01), 6976.

Collins, J. (2006). Working papers in urban language and literacies (Paper 41), null(September), null.

Education, E., \& Program, S. (2014). the Multifaceted Dimensions of English Linguistics, Literature and Education, (October), 10-11.

Isti, R. (2013). An Analysis of Code Mixing and Code Switching On Twitter Timeline of Class 8C of English Education Program of Muhammadiyah University of Purworejo and Its Application In Language Teaching.

Khairunas, S. (2018). Code-Switching in Tv Talk Show Program Entitled "Sarah Sechan" on Net Tv. Wanastra, XII(I), 38-46. Retrieved from http://ejournal.nusamandiri.ac.id/ejurnal/index.php/progressive/issue/view/35

Khairunas, S., \& Inggris, B. (2016). CODE SWITCHING AND CODE MIXING IN MY STUPID BOSS NOVEL, I(1), 60-67.

Kurniati, I. (2014). a Sociolinguistics Analysis of Code Mixing on Nine Summer Ten Autumns Novel By Iwan Setiawan, 1-40. Retrieved from http://repository.uinjkt.ac.id/dspace/bitstream/123456789/29663/1/Indira Kurniati-Fah.pdf

Maftoon, P. (2016). c r v i f, (May 2011).

Nuryanto, S. (2014). Code Mixing Used in Sby'S Political Speeches Period 2009 - 2014. English Education And Teacher Training Education, VII, 82-102.

Pendidikan Bahasa, J., Fkip, S., \& Banjarmasin, U. (2019). SOCIOLINGUISTICS: A Language Study in Sociocultural Perspemctives.

Putra, O. P., \& Yastanti, U. (2018). Code Switching and Code Mixing in Critical Eleven Novel by Ika Natassa. Scope : Journal of English Language Teaching, 2(02), 160. https://doi.org/10.30998/scope.v2i02.2379

Thanissaro, P. N., \& Kulupana, S. (2015). Buddhist teen worldview: Some normative background for health professionals. Contemporary Buddhism, 16(1), 28-42. 
IJEAL (International Journal of English Education and Applied Linguistic)

Volume : 1 | Number 2 | August 2021 | E-ISSN : 2787-9482 | DOI: doi.org/ijeal.v1n1.1029

https://doi.org/10.1080/14639947.2015.1006801

Yastanti, U. (2016). Campur Kode Pada Pidato Presiden Sby Dalam Perayaan Hut Ke-69 Republik Indonesia. LINGUA: Journal of Language, Literature and Teaching, 13(2), 255.

https://doi.org/10.30957/lingua.v13i2.180 